\title{
Epidemiological Aspects of Cervicofacial Cellulitis Due to Dental Origin in the City of Ouagadougou (Burkina Faso)
}

\author{
Wendpouiré Patrice Laurent Guiguimdé1,2*, Kouamé Patrice Attogbain³ , Jocelyne V. W. Garé1,2, \\ Yamsoulougri C. L. Ouédraogo4, Mathieu Millogo ${ }^{1,2}$, Tarcissus Konsem ${ }^{1,2}$ \\ ${ }^{1}$ Training and Research Unit in Health Sciences (UFR/SDS), Joseph Ki Zerbo University, Ouagadougou, Burkina Faso \\ ${ }^{2}$ Department of Odontostomatology and Maxillofacial Surgery, Yalgado Ouédraogo University Hospital, Ouagadougou, Burkina \\ Faso \\ ${ }^{3}$ Department of Surgery, UFR of Odonto-Stomatology, Félix Houphouët-Boigny University of Abidjan, Abidjan, Republic of Côte \\ d'Ivoire \\ ${ }^{4}$ Department of Odontostomatology and Maxillofacial Surgery, Bogodogo University Hospital Center, Ouagadougou, Burkina \\ Faso \\ Email: *guiguimdew@yahoo.fr
}

How to cite this paper: Guiguimdé, W.P.L. Attogbain, K.P., Garé, J.V.W., Ouédraogo, Y.C.L., Millogo, M. and Konsem, T. (2021) Epidemiological Aspects of Cervicofacial Cellulitis Due to Dental Origin in the City of Ouagadougou (Burkina Faso). Open Journal of Stomatology, 11, 399-410.

https://doi.org/10.4236/ojst.2021.1110035

Received: August 30, 2021

Accepted: September 27, 2021

Published: September 30, 2021

Copyright (c) 2021 by author(s) and Scientific Research Publishing Inc. This work is licensed under the Creative Commons Attribution International License (CC BY 4.0).

http://creativecommons.org/licenses/by/4.0/

\begin{abstract}
Background: Head and neck cellulitis of dental origin are polymicrobial bacterial infections involving the cellulo-adipose spaces of the face and neck. The objective of this work was to describe the epidemiological and clinical profile of patients with head and neck cellulitis. Methods: This was a cross-sectional study conducted from 1 January to 30 June 2020. All patients consulting for cervico-facial cellulitis of dental origin in 2 university hospitals in Ouagadougou were included in the study. The usual parameters of descriptive statistics were estimated for each variable. Results: Two hundred and ninety-two cases (184 men and 108 women), aged 3 to 85 years were collected. The 25 - 35 years old were the most affected (33\%). Decay was the leading dental cause (95.6\%). The delay in consultation was included within 7 days in $74.66 \%$ of cases. Ninety-one-point forty-four percent of patients had poor oral hygiene. Diffuse cellulitis was the most common (64.04\%) and peri-mandibular regions were the most invaded $(42.81 \%)$. Conclusion: The frequencies observed in our study allow us to conclude that cervicofacial cellulitis of dental origin is still frequent and affects a young and disadvantaged population.
\end{abstract}

\section{Keywords}

Cervicofacial Cellulitis, Odontogenic Infection, Epidemiological and Clinical Profile, Ouagadougou 


\section{Introduction}

Cervicofacial cellulitis of dental origin is an infectious process of the celluloadiputic tissue of the face with a dental starting point, often with unclear boundaries and extensive tendency [1]. They involve the vital prognosis due to the speed of evolution and gravity of complications [2]. If, cervico-facial cellulitis is clearly regressing in developed countries, they are still very present. Surprisingly, in recent years we have noted their increasing incidence in developing countries [3]-[8]. In Burkina Faso, there is a resurgence of cellulitis due to the lack of access to health care, delayed consultation of patients, the complexity of therapeutic itinerary of patients, self-medication, poor use of antibiotics, and the impoverishment of the population... No study on the scale of the city of Ouagadougou, which includes several hospitals and has taken stock of the epidemiological situation, has yet been carried out on cervicofacial cellulitis due to dental origin, hence the interest of this work. The aim of this study is to examine the different epidemiological and clinical aspects of these pathologies in Ouagadougou.

\section{Material and Methods}

Our study was conducted in the Stomatology and Maxillofacial Surgery (S/CMF) departments of the Yalgado Ouédraogo University Hospital (CHU-YO) and the Bogodogo University Hospital (CHU-B).

This was a descriptive cross-sectional study. Data were collected from January 1 to December 31, 2020. All patients consulting for cervico-facial cellulitis due to dental origin, regardless of sex or age, were included in the study, and consent was obtained.

The data were collected using a collection form developed for this purpose (attached). The variables studied concerned socio-demographic data (age, sex, level of education, marital status, socio-professional category, residence and resources), the characteristics of the patients on admission (reason for consultation, time of consultation, medical history, general signs, etc.), the characteristics of patients in the hospital, and the characteristics of patients in the community, medical history, general signs, tobacco, alcohol and/or drug consumption, self-medication and medication taken and clinical data (oral hygiene, etiology of cellulitis, clinical type of cellulitis, topography of the lesion, teeth concerned).

Data entry was performed using EPIDATA software. The analysis, which was done with the help of $\mathrm{R}$ software version 4.1.0, consisted of a descriptive analysis of the data. The usual parameters of descriptive statistics were estimated for each variable. These were the proportions for the qualitative variables, the average and the standard deviation for the quantitative variables whose distribution was normal.

The anonymity of patients and the confidentiality of collected information were preserved. No identifying data were recorded in the database or used in the analysis. 


\section{Results}

During the period of our study, we recorded 292 cases of cervico-facial cellulitis of dental origin. The average monthly number of cellulitis cases was 24.3 patients. There were 3 peaks in frequency in April (34 cases), June (34 cases), and October (43 cases) (Figure 1).

\section{Socio-demographic characteristics}

The average age of patients was $35.41 \pm 16.64$ years. The extreme ages were 3 and 85 years. Table 1 shows the age distribution according to age ranges.

The sex ratio was 1.73. Patients not attending school represented $45.2 \%$ of our study population. There were two (02) patients covered by health insurance and $75.95 \%$ of patients lived in the central region. Table 2 shows the distribution of patients according to their socio-demographic characteristics.

\section{Patient characteristics at admission}

The majority of patients consulted within the first week of the onset of symptoms (74.6\%) and pain was the main reason for the consultation (93.2\%); 49.3\% used self-medication before the consultation (Table 3).

The general signs presented by the patients on admission are described in $\mathrm{Ta}-$ ble 4. Trismus was the dominant sign (66.7\%) followed by dysphagia (56.7), conjunctival pallor (42.52\%), odynophagia (35.96\%), hyperthermia (33.79\%).

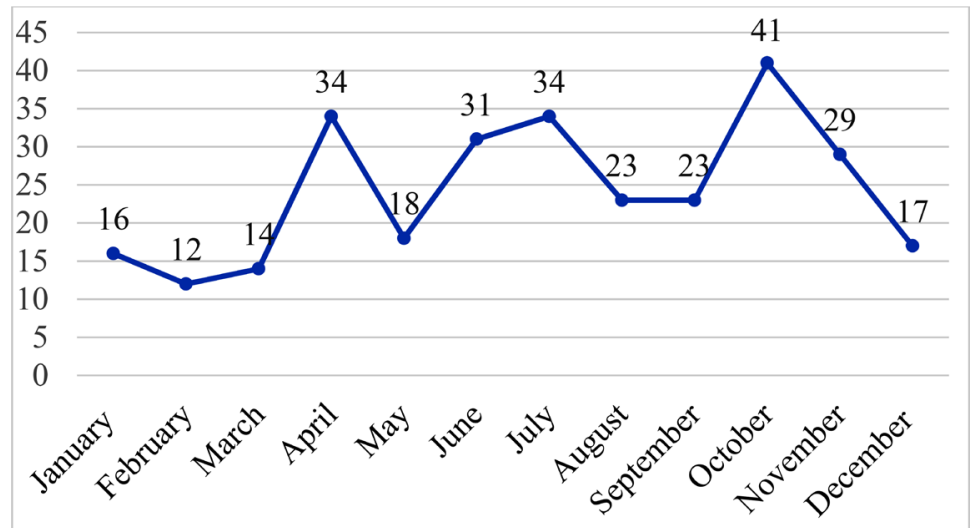

Figure 1. Monthly incidence of cervicofacial cellulitis cases.

Table 1. Distribution of patients by age range.

\begin{tabular}{ccccc}
\hline Age & Number $\mathbf{n}=\mathbf{2 9 2}$ & $(\%)$ & Mean & Standard deviation \\
\hline Years & & & 35.41 & 16.64 \\
$<15$ ans & 26 & 8.9 & & \\
{$[15-25]$} & 38 & 13.0 & & \\
{$[25-35]$} & 99 & 33.0 & \\
{$[35-45]$} & 46 & 15.0 & \\
{$[45-55]$} & 40 & 13.6 & & \\
{$[55-65]$} & 23 & 7.8 & \\
$\geq 65$ ans & 20 & 6.8 & \\
\hline
\end{tabular}


Table 2. Distribution of patients according to socio-demographic characteristics.

\begin{tabular}{|c|c|c|c|}
\hline Variables & Modalities & Number $=292$ & $(\%)$ \\
\hline \multicolumn{4}{|l|}{ Gender } \\
\hline & Male & 184 & 63.0 \\
\hline & Female & 108 & 37.0 \\
\hline \multicolumn{4}{|c|}{ Marital status } \\
\hline & Single & 95 & 32.5 \\
\hline & In couple & 197 & 67.5 \\
\hline \multicolumn{4}{|c|}{ Study level } \\
\hline & Not in school & 132 & 45.2 \\
\hline & Primary & 102 & 34.9 \\
\hline & Secondary and higher & 58 & 19.9 \\
\hline \multicolumn{4}{|c|}{ Socio-professional category } \\
\hline & Employed & 26 & 8.9 \\
\hline & Self-employed & 100 & 34.2 \\
\hline & Without remuneration & 148 & 50.7 \\
\hline & Other & 18 & 6.2 \\
\hline \multicolumn{4}{|l|}{ Resource } \\
\hline & Indigent & 99 & 33.9 \\
\hline & Insurance & 2 & 0.7 \\
\hline & Private & 191 & 65.4 \\
\hline \multicolumn{4}{|l|}{ Residence } \\
\hline & Central region & 221 & 76.0 \\
\hline & Other regions & 65 & 22.3 \\
\hline & Other countries & 5 & 1.7 \\
\hline
\end{tabular}

Table 3. Distribution of patients according to patient characteristics at admission.

\begin{tabular}{lccc}
\hline \multicolumn{1}{l}{ Variables } & Number $\mathbf{n}=\mathbf{2 9 2}$ & (\%) \\
\hline Reasons for consultation & 272 & $\mathbf{9 3 . 2}$ \\
Pain & 20 & 6.8 \\
Swelling & & \\
Consultation deadlines & 218 & $\mathbf{7 4 . 6}$ \\
$\leq 7$ days & 37 & 12.7 \\
{$[7,14]$} & 37 & 12.7 \\
M15, 540] & & 1.0 \\
Medical history & Cardiovascular disease & 3 & 2.4 \\
\hline
\end{tabular}




\section{Continued}

$\begin{array}{lcc}\text { Pregnancy } & 9 & 3.1 \\ \text { Immunosuppression (HIV) } & 3 & 1.0 \\ \text { UGD } & 4 & 1.3 \\ \text { Mental illness } & 2 & 0.7 \\ \text { Other* } & 5 & 1.7 \\ \text { No } & 259 & 88.7\end{array}$

Self-medication

Yes

Types of medication

Antibiotic
Anti-inflammatory
Traditional
Analgesics

Origin of the drugs

$$
\begin{aligned}
& \text { Officine } \\
& \text { Personal or family reserve } \\
& \text { Gift (friend, relative) } \\
& \text { Market or street }
\end{aligned}
$$

Alcohol consumption

Tobacco use
Yes
81

Drug use

Yes

5

1.7

${ }^{*}$ Herniated disc, Epistaxis, Sciatica, Asthma, Renal insufficiency.

Table 4. Distribution of patients according to general signs.

\begin{tabular}{ccc}
\hline General signs & Number $\mathbf{n}=292$ & $\%$ \\
\hline Asthenia & 16 & 5.5 \\
Anorexia & 22 & 7.6 \\
Altered Consciousness & 6 & 2.1 \\
Thoracic Diffusion & 6 & 2.1 \\
Hyperthermia & 98 & 33.8 \\
Altered General Condition & 27 & 9.3 \\
Dehydration & 15 & 5.1 \\
Emphysema & 0 & 0 \\
Respiratory distress & 10 & 3.4 \\
Trismus & 195 & 66.7 \\
\hline
\end{tabular}




\begin{tabular}{|c|c|c|}
\hline Continued & & \\
\hline Dyspnea & 13 & 4.4 \\
\hline Odynophagia & 105 & 35.9 \\
\hline Dysphagia & 165 & 56.7 \\
\hline Dysphonia & 20 & 6.8 \\
\hline Bleeding & 13 & 4.4 \\
\hline Conjunctival pallor & 130 & 42.5 \\
\hline Tonsillitis & 4 & 1.4 \\
\hline Pharyngeal abscess & 9 & 3.1 \\
\hline
\end{tabular}

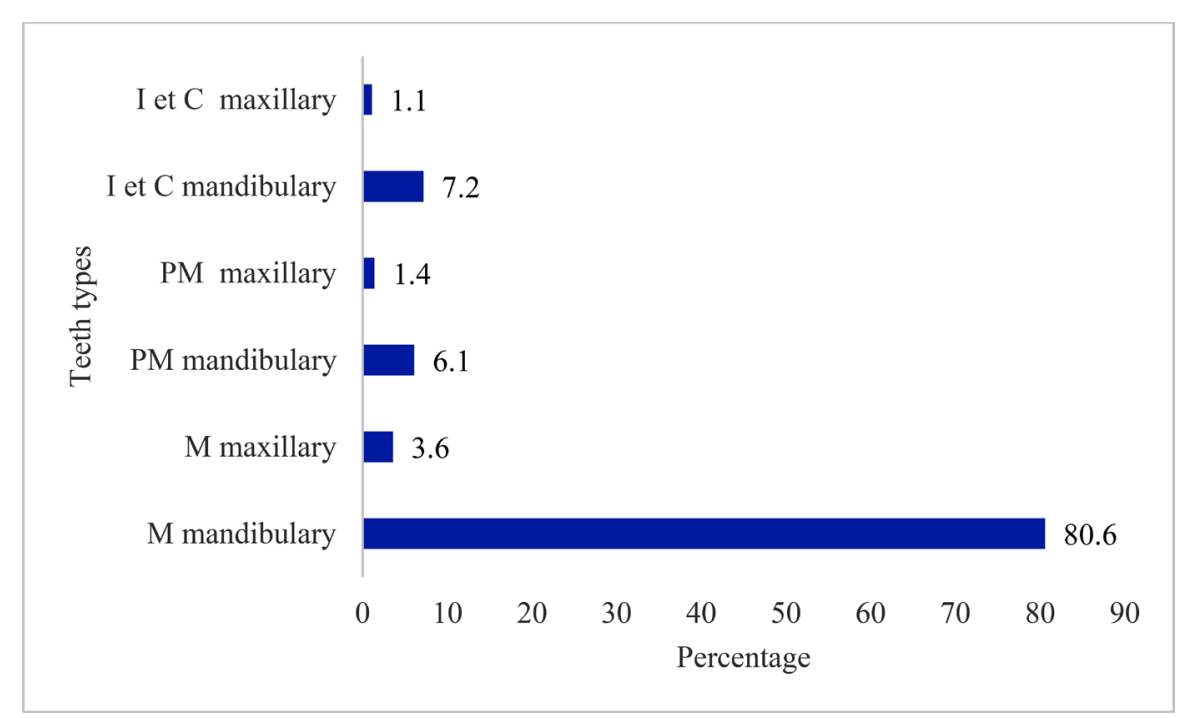

I and $\mathrm{C}=$ incisors and canines. $\mathrm{PM}=$ premolars. $\mathrm{M}=$ molars.

Figure 2. Distribution of the frequency of causal teeth.

\section{Clinical aspects}

Poor oral hygiene was present in $91.44 \%$ of the patients. Dental caries were the main etiology of cervicofacial cellulitis of dental origin, and mandibular molars (temporary and permanent) were the most affected (Figure 2). Diffuse suppurative cellulitis (Photo 1) was the predominant clinical form and the peri-mandibular site (Photo 2) was the most common topography. Table 5 shows the distribution of clinical characteristics of cellulitis.

\section{Discussion}

\section{Socio-demographic characteristics}

Two hundred and ninety-two cases of cervicofacial cellulitis were recorded during our study period, representing a monthly hospital frequency of 24.3 cases. The hospital frequency of cervicofacial cellulitis is largely underestimated in our context because all cases do not reach our hospitals [7]. Despite this underestimation, the frequency of cases in our series remains high and we note an annual increase in cervicofacial cellulitis, as observed by other African authors: 


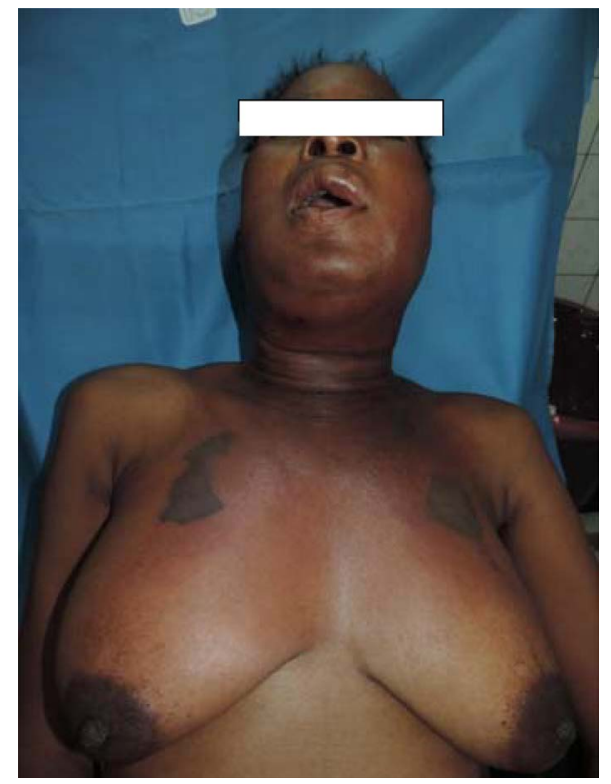

Photo 1. 46-year-old patient with diffuse cellulitis affecting the facial, cervical and thoracic regions with necrotic areas, who died in septic shock (Source: S/CMF Department of the CHU-YO).

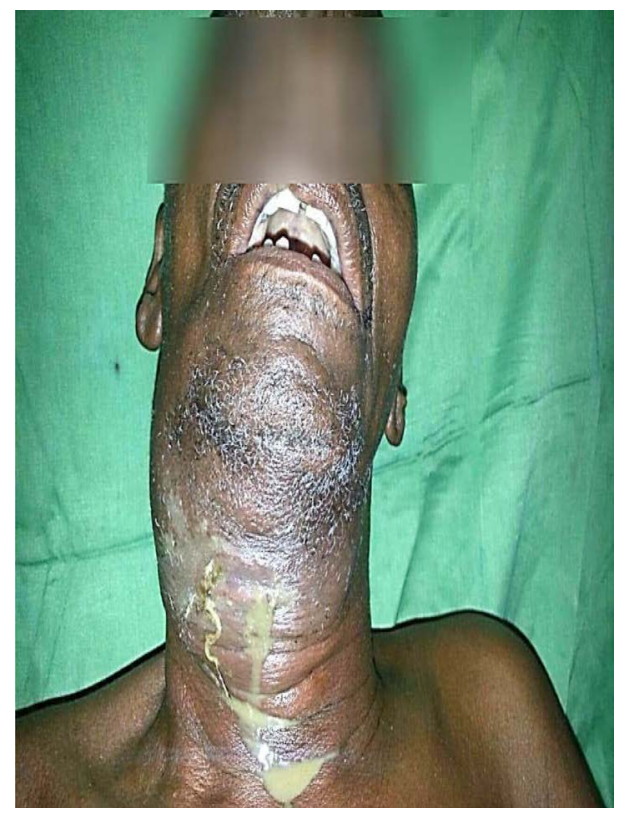

Photo 2. 69-year-old patient with diffuse cervicofacial cellulitis with compression of the VADS and a greenish pus flow (Source: S/CMF Department of the YO University Hospital).

9.66 cases per year in the series of Ngouoni in Congo [9], 11.2 cases per year in that of Rakotoarison in Madagascar [10], 14.8 cases per year in that of Ag Mohammed in Mali [11]. This increase in the number of cases of cellulitis seems to be due to a decrease in the immune defense caused by abusive self-medication with anti-inflammatory drugs, instead of using non-anti-inflammatory analgesics [12]. In addition, the misuse of antibiotics, still in self-medication, causes an 
Table 5. Shows the distribution of clinical forms of cellulitis.

\begin{tabular}{|c|c|c|c|}
\hline Variables & Modalities & Number $n=292$ & $(\%)$ \\
\hline \multicolumn{4}{|c|}{ Oral hygiene } \\
\hline & Good hygiene & 25 & 8.6 \\
\hline & Poor hygiene & 267 & 91.4 \\
\hline \multicolumn{4}{|c|}{ Etiologies of cellulite } \\
\hline & Tooth decay & 279 & 95.6 \\
\hline & Post extraction & 10 & 3.4 \\
\hline & Others $^{\star}$ & 4 & 1.0 \\
\hline \multicolumn{4}{|c|}{ Clinical signs of cellulitis } \\
\hline & Circumscribed serous & 25 & 8.5 \\
\hline & Circumscribed suppurative & 76 & 26.0 \\
\hline & Circumscribed gangrenous & 4 & 1.4 \\
\hline & Diffuse serous & 16 & 5.5 \\
\hline & Diffuse suppurated & 162 & 55.5 \\
\hline & Diffuse gangrenous & 9 & 3.1 \\
\hline \multicolumn{4}{|c|}{ Topography of the cellulitis } \\
\hline & Peri-maxillary & 121 & 41.5 \\
\hline & Peri-mandibular & 125 & 42.8 \\
\hline & Cervico-thoracic & 31 & 10.6 \\
\hline & Periorbital & 3 & 1.0 \\
\hline & Temporo-Masseterine & 9 & 3.1 \\
\hline & Other** & 3 & 1.0 \\
\hline
\end{tabular}

${ }^{\star}$ Periodontal disease, Alveolodentomaxillary trauma; ${ }^{* *}$ Not specified.

increase in the resistance and virulence of germs, as well as the inaccessibility of oral care to our poor populations [7] [13].

It was a young adult condition as evidenced by the most affected average age (35.41 \pm 16.64 years) and the majority' of the data concerning Africa [6] [14] [15] [16]. Indeed, young people represent a very large proportion of the population in African countries. In addition, the abuse of cariogenic foods and the frequency of wisdom teeth evolution accidents would be inherent risk factors for this age group [8] [17].

The male predilection for dental cellulitis has been reported in most of the studies conducted throughout the world, particularly in Africa [6] [10] [17] [18] [19] [20] [21]. In men, risk factors have been suggested (poor oral hygiene, alcohol, smoking) [2]. In women, in addition to hygiene, a better immune response has also been mentioned [16]. However, studies conducted in Africa and Europe have reported a predominance of women [8] [19]. This reversal of the trend would be explained by a greater susceptibility to pain and infection in women, as well as by greater illiteracy, which would favor persistent recourse to 
traditional practitioners [8]. The low socioeconomic and educational levels of our patients also play an important role in the genesis of these cervicofacial cellulites [6] [7] [15] [22] [23]. In our study, the majority of the patients were non-occupational subjects who could not seek care due to lack of financial means. Indeed, the lack of financial means that do not allow access to adequate care often makes people opt for self-medication, recourse to radiotherapists and late consultations. The same is true for the level of education, the more educated people are, the more they pay attention to their oral health.

\section{Clinic}

We recorded a delay in consultation ranging from 01 to 540 days, with an average of 13.86 days. Delays in consultation are explained by self-medication and traditional treatments on the one hand, and by financial inaccessibility to care on the other. As in several series, we also found in our sample the favourable factors frequently incriminated in the occurrence and spread of cellulitis, such as pregnancy, diabetes, HIV infection, alcohol, tobacco and drug addiction [6] [9] [14] [23].

The majority of the patients $(91.44 \%)$ had poor oral hygiene. It was established that poor oral hygiene is one of the key factors to be considered. This result only supports the data usually reported on the role of defective hygiene as a factor favoring the occurrence of cellulitis [4] [6] [16] [24].

The diagnosis of cervicofacial cellulitis is clinical based on the conjunction of a severe infectious condition and physical cervicofacial signs. Often, a recent history of dental avulsion, dental care or dental abscess is found, sometimes still evolving. The cervico-facial swelling, almost constant, is inflammatory and painful. This swelling is highly suggestive of cellulitis. The association with trismus and odynophagia is usual and the general signs are rarely absent. Dental causes, as many studies have shown, were dominated by dental necrosis subsequent to caries [6] [10] [25]. In our series, $95.55 \%$ of cases were indeed due to this etiology. The carious pathology is often neglected, hence the high rate in the occurrence of cervico-facial cellulitis. Our study showed that $64.1 \%$ of cellulitis were diffuse forms and $35.95 \%$ were circumscribed forms. Diallo A, in Ouagadougou in an older study on cervico-facial cellulitis of dental origin at CHUYO, found $73.4 \%$ circumscribed cellulitis and $11.8 \%$ diffuse cellulitis [26], Bengondo $\&$ al. found $84.3 \%$ circumscribed cellulitis and $15.7 \%$ diffuse forms in their study in Yaounde [18]. Niang et al. in Dakar reported $90.3 \%$ of circumscribed cellulitis and $9.7 \%$ of diffuse cellulitis [14]. Delayed consultations, self-medication, particularly the abusive use of anti-inflammatory drugs instead of analgesics could explain the spread of circumscribed cellulitis. Non-steroidal anti-inflammatory drugs are frequently mentioned in the literature as factors likely to promote the onset or progression of the infectious process. They are generally taken alone or in combination with antibiotic therapy, which is often inappropriate.

The predominant sites of cellulitis in our study were by far peri-mandibular (42.81\%) and peri-maxillary (41.44\%). Bengondo et al. reported $78.4 \%$ of peri-mandibular forms and $21.6 \%$ of peri-maxillary forms. The peri-mandibular 
forms are the most important because the mandibular teeth, particularly the molars, are the most incriminated in the literature review [6] [7] [14] [18] [27]. Indeed, mandibular molars are very exposed to caries and its complications because of their volume, their morphology (grooves on the occlusal surface) and their appearance on the arch at an age when the principles and techniques of oral hygiene are not perfectly assimilated. The ease of diffusion of the infection in the cellulo-fatty tissue of the peri-mandibular regions would also explain the frequency of cellulitis on the lower level of the face. The lower frequency of cellulitis in the maxilla is due to the depth of the vestibule and the lack of cellular tissue, particularly in the palate where the adherent fibro-mucosa limits the spread of infection, leading to the formation of a subperiosteal abscess [15] [27].

\section{Conclusion}

Cervicofacial cellulitis is a frequent and varied pathology in its clinical forms, in full recrudescence in odontostomatology. The young subject with low economic power is the most affected. Self-medication and recourse to traditional treatment would delay consultation and worsen the prognosis. The prevention of cellulitis requires all the means of prevention of caries and a regular odontological examination which allows diagnosing dental lesions and treating them early in order to avoid the development of complications.

\section{Conflicts of Interest}

The authors declare no conflicts of interest regarding the publication of this paper.

\section{References}

[1] Loppin, M., Adamski, H., Larrègue, M., Cadre, B., Godey, B. and Chevrant-Breton, J. (2006) Ulcérations cervicofaciales liées à un foyer infectieux dentaire chez l'enfant. Archives de Pédiatrie, 13, 149-151. https://doi.org/10.1016/j.arcped.2005.10.018

[2] Benzarti, S., Mardassi, A., Mhamed, R., Hachicha, A., Brahem, H., Akkari, K., et al. (2007) Les cellulites cervico-faciales d'origine dentaire: A propos de 150 cas. Journal Tunisien d ORL et de Chirurgie Cervico-Faciale, 19, 24-28. https://doi.org/10.4314/jtdorl.v19i1.57887

[3] Zegbeh, N.E.K., Digbeu, O.K.E., Bérété, P.I.J., Teti, F.L., Goulé, A.M., Crezoit, G.E. (2020) Facial Cellulitis of Dental Origin: Experiments from the University of Bouaké Health Centre (Cote d'Ivoire). Open Journal of Stomatology, 10, 97-105. https://doi.org/10.4236/ojst.2020.105011

[4] Fofana, A., Keita, M., Beye, S., Doumbia-Singaré, K., Drame, B., Timbo, S., et al. (2017) La Cellulite cervico-faciale et thoracique en milieu défavorisé à Ségou au Mali. Revue Malienne d' Infectiologie et de Microbiologie, 9, 2-10.

[5] Gyébré, Y.M.C., Gouéta, A., Zaghré, N., Sérémé, M., Ouédraogo, B.P. and Ouoba, K. (2016) Complications of Cervicofacial Cellulitis Supported in University Hospital Yalgado Ouedraogo. International Journal of Otolaryngology and Head \& Neck Surgery, 5, 115-120. https://doi.org/10.4236/ijohns.2016.53019

[6] Haitami, S., Kissi, L., Hamza, M., Rifki, C. and Yahya, I.B. (2016) Les cellulites cer- 
vico-faciales d'origine dentaire: Étude transversale. Rev Odont Stoma, 45, 300-309.

[7] Konsem, T., Millogo, M., Ouédraogo, D., Zidwemba, N. and Ouoba, K. (2012) Les cellulites diffuses cervico-faciales au centre hospitalier universitaire Yalgado Ouédraogo (Ouagadougou Burkina Faso). Revue Internationale du College D' Odonto-Stomatologie Africain et de Chirurgie Maxillo-Faciale, 19, 30-34.

[8] Dia-Tine, S., Gassama-Barry, B., Niang, P., Seck, O. and Kebe, N. (2008) Aspects cliniques des cellulites périmaxillaires dans la région de Dakar. Revue Internationale du College D'Odonto-Stomatologie Africain et de Chirurgie Maxillo-Faciale, 15, 28-33.

[9] Ngouoni, B., Ngotne, R., Mbitsi-Ngoma, H. and Mosimbi, N. (2008) Cellulites diffuses sous mandibulaires d'origine dentaire. Revue Internationale du College D'Odonto-Stomatologie Africain et de Chirurgie Maxillo-Faciale, 15, 38-42.

[10] Rakotoarison, R.A., Ramarozatovo, N.P., Rakoto, F.A. and Rakotovao, F.J. (2008) Cellulites cervico-faciales: À propos de 41 cas. Médecine Buccale Chir Buccale, 14, 35-39.

[11] Ag Mohamed, A., Diallo, M., Keita, M., Sylla, F.T. and Traore, J. (2008) Cellulite peri-orbitaire et poly sinusite paranasale: Analyse de deux cas colliges au service ORL de l'hopital Gabriel Toure de Bamako; Mali. Cas clinique. Mali Méd, 23, 59-62.

[12] Barnabe, D., Briche, T. and Raynal, M. (2003) Les cellulites cervicales. Rev Off Soc Fr ORL Chir Cervicofac, 77, 8-12.

[13] Potard, G., Marianowski, R., Fortun, C., Raybaud, O. and Preveraud, D. (2000) Cellulites de la face et du cou: A propos de 13 cas. Journal français doto-rhino-laryngologie, 49, 325-337.

[14] Niang, P., Ba, A., Tamba-Fall, A., Dia Tine, S., Kounta, A., Diop, R., et al. (2011) Aspects épidémiologiques Et cliniques des cellulites prémaxillaires: Expérience d'un service de stomatologie Au Sénégal. Revue Internationale du College D'Odonto-Stomatologie Africain et de Chirurgie Maxillo-Faciale, 18, 33-38.

[15] Razafindrabe, J., Randriamanantenasoa, V., Andrianasolo, M., Radaviarison, J., Rasoarimasy, V. and Rakotovao, J. (2007) Epidemiological and Clinical Aspect of Dental Cellulitis in Antananarivo. Journal of Medical Sciences, 7, 1108-1111. https://doi.org/10.3923/jms.2007.1108.1111

[16] El Ayoubi, A., El Ayoubi, F., Mas, E., Guertite, A., Boulaïch, M., Essakalli, L., et al. (2009) Cellulites cervico-faciales diffuses d'origine dentaire: À propos de 60 cas. Médecine Buccale Chir Buccale, 15, 127-135.

[17] Dubernard, C., Bellanger, S., Chambon, G., Léon, H., Torres, J.-H. and Lozza, J. (2009) Cellulite d'origine dentaire engageant le pronostic vital: À propos d'un cas. Médecine Buccale Chir Buccale, 15, 119-125.

[18] Bengondo, C., Bita, R., Avang, N., Mengong, H. and Bengono, G. (2006) Cellulites et phlegmons d'origine dentaire au CHU de Yaoundé. Odonto-Stomatologie Tropicale, Tropical Dental Journal, 113, 23-26.

[19] Carter, L.M. and Layton, S. (2009) Cervicofacial Infection of Dental Origin Presenting to Maxillofacial Surgery Units in the United Kingdom: A National Audit. British Dental Journal, 206, 73-78. https://doi.org/10.1038/sj.bdj.2009.4

[20] Flynn, T.R., Shanti, R.M., Levi, M.H., Adamo, A.K., Kraut, R.A. and Trieger, N. (2006) Severe Odontogenic Infections, Part 1: Prospective Report. Journal of Oral and Maxillofacial Surgery, 64, 1093-1103.

https://doi.org/10.1016/j.joms.2006.03.015

[21] Zhang, C., Tang, Y., Zheng, M., Yang, J., Zhu, G., Zhou, H., et al. (2010) Maxillofa- 
cial Space Infection Experience in West China: A Retrospective Study of 212 Cases. International Journal of Infectious Diseases, 14, e414-e417. https://doi.org/10.1016/j.ijid.2009.08.002

[22] Bennani-Baïti, A.A., Benbouzid, A. and Essakalli-Hossyni, L. (2015) Cervicofacial Cellulitis: The Impact of Non-Steroidal Anti-Inflammatory Drugs. A Study of 70 Cases. European Annals of Otorhinolaryngology, Head and Neck Diseases, 132, 181-184. https://doi.org/10.1016/j.anorl.2015.06.004

[23] Ke, B., Buraima, F., Yoda, M., Traoré, K., Kouassi, Y., Tanon-Anoh, M., et al. (2014) Cellulites cervico-faciales au centre hospitalo-universitaire de Yopougon (Abidjan-Côte D'ivoire). Revue Internationale du College D'Odonto-Stomatologie Africain et de Chirurgie Maxillo-Faciale, 21, 5-10.

[24] Doumbia-Singare, K., Timbo, S.K., Keita, M., Ag Mohamed, A., Guindo, B. and Soumaoro, S. (2014) Cellulite cervico-faciale au cours de la grossesse. À propos d'une série de 10 cas au Mali. Bulletin de la Société de pathologie exotique, 107, 312-316. https://doi.org/10.1007/s13149-014-0401-6

[25] DeAngelis, A.F., Barrowman, R.A., Harrod, R. and Nastri, A.L. (2014) Review Article: Maxillofacial Emergencies: Oral Pain and Odontogenic Infections. Emergency Medicine Australasia, 26, 336-342. https://doi.org/10.1111/1742-6723.12266

[26] Diallo, A. (2004) Les cellulites cervico-faciales d'origine dentaire: aspects épidémiologiques, cliniques et thérapeutiques au centre hospitalier universitaire Yalgado Ouédraogo (Burkina Faso). A propos de 127 cas. Thèse de medicine, Université de Ouagadougou, Burkina Faso.

[27] Eboungabeka Trigo, E.R.M., Dibansa, O. and Lekesse, C. (2020) Odontogenic Cervico-Facial Cellulitis at the University Hospital of Brazzaville: About 431 Cases. Open Journal of Stomatology, 10, 19-27. https://doi.org/10.4236/ojst.2020.102003

\section{Annex}

https://docs.google.com/document/d/13BOeqHIFvcto0KwaYhrym7hkpK7sl-pm ledit?usp $=$ sharing\&ouid $=103872500155260047162 \& \mathrm{rtpof}=$ true $\& s d=$ true 